\title{
Identidade Profissional da Enfermeira no Brasil: Passado, Presente e Futuro
}

\author{
Pereira, Juliana Guisardi; Oliveira, Maria Amélia de Campos; Yamashita, Cintia \\ Hitomi
}

Escola de Enfermagem da USP — julianaguisardi@gmail.com

Introdução: Passados mais de 100 anos da profissionalização da Enfermagem, a identidade profissional da enfermeira continua marcada por imagens que produzem estereótipos sobre a profissão, obstaculizando a visibilidade social de seu trabalho: o cuidado individual e coletivo. As amplas transformações sociais e econômicas atuais ocasionaram mudanças no mundo do trabalho e, por conseguinte, nas identidades, possibilitando às enfermeiras, enquanto grupo profissional, reivindicar novas identidades que superem dialeticamente as marcas do passado. Objetivo: Evidenciar as marcas históricas que incidem sobre a identidade profissional da enfermeira e suas repercussões na atualidade e refletir sobre possibilidades de sua superação. Método: Realizou-se uma revisão integrativa da literatura nas bases de dados Pubmed, BVS e Scielo, a partir do cruzamento das palavras: "identidade X enfermeira" e "identidade X enfermagem", publicados até junho de 2013, cujos resumos estivessem disponíveis e informassem objetivos e metodologia utilizada. dos 1.450 artigos incialmente resultantes, foram selecionados 108, 77 em língua inglesa e 31 em português. Resultados: na identidade profissional da enfermeira é possível identificar marcas de gênero (atividade feminina associada ao cuidado materno e doméstico, determinada pela posição da mulher na sociedade; enfermeiras como mulheres puras ou desqualificadas) do modelo religioso (ideais humanitários como bondade e devotamento, associados ao serviço religioso e às obras da caridade; enfermeiras como anjos e santas); do modelo militar (hierarquia, disciplina, ajustamento, obediência, espírito de grupo, sentimentos de nacionalidade, patriotismo e neutralidade política e científica; prática tarefeira e servil); do contexto histórico social (do surgimento da Enfermagem moderna, ou seja, a Inglaterra vitoriana, os aspectos cultural, histórico, econômico, a divisão técnica e social do trabalho, as ideologias e os modelos assistenciais, a formação e a inserção no trabalho, as transformações estruturais do emprego); de símbolos e ritos (uniformes, insígnias, touca, fachadas e espaços internos das escolas, estátuas, juramentos e cerimônias religiosas) e de mitos e padrões (Florence Nigntingale, Anna Nery e a "escola padrão" Anna Nery, os valores morais e a busca de cientificidade para a profissão). Conclusões: na imagem pública, predominam identificações da Enfermagem como prática feminina, como prática leiga ou de pouca qualificação, como profissão auxiliar ao exercício da Medicina; e a influência de estereótipos forjados durante a formação e a prática profissional. a formação inicial em Enfermagem, como espaço privilegiado para a construção da identidade profissional, possibilita a abordagem crítica e contextualizada que instigue a legitimação de competências e de imagens de si associadas às identidades reivindicadas pelas enfermeiras.

\footnotetext{
Pereira, Juliana Guisardi; Oliveira, Maria Amélia de Campos; Yamashita, Cintia Hitomi. Identidade Profissional da Enfermeira no Brasil: Passado, Presente e Futuro. In: Anais do Congresso Internacional de Humanidades \& Humanização em Saúde [= Blucher Medical Proceedings, num.2, vol.1]. São Paulo: Editora Blucher, 2014. ISSN 2357-7282

DOI 10.5151/medpro-cihhs-10361
} 